\title{
Spatial Analysis of Soil Chemical Properties of Bastar District, Chhattisgarh, India
}

\author{
P. Smriti Rao ${ }^{*}$, Tarence Thomas ${ }^{1}$, Amit Chattree ${ }^{2}$, \\ Joy Dawson ${ }^{3}$ and Narendra Swaroop ${ }^{1}$
}

${ }^{1}$ Department of Soil Science, ${ }^{2}$ Department of Chemistry, ${ }^{3}$ Department of Agronomy, Sam Higginbottom University of Agriculture, Technology \& Sciences- 211007 Allahabad, U.P., India

*Corresponding author

\begin{abstract}
A B S T R A C T
Mapping of soil properties is an important operation as it plays an important role in the

Keywords

Geostatistics,

Coefficient of

variance, Ordinary

kriging, etc.

Article Info

Accepted:

17 March 2019

Available Online:

10 April 2019

knowledge about soil properties and how it can be used sustainably. The study was carried out in a Bastar district, Chhattisgarh state, India in order to map out some soil characteristics and assess their variability within the area. Samples were collected from the 4 sampling sites, Kesloor and Raikot (NH-16), Adawal and Nagarnar (NH-43) in Jagdalpur. From each site, 6 samples of soils (with three replications) from $20 \mathrm{~m}, 60 \mathrm{~m}$ and $500 \mathrm{~m}$ (control site) distance from the edge of national highway at two soil depths, 0-20 $\mathrm{cm}$, and 20-40 cm were collected respectively. The soil samples were air-dried, crushed and passed through a $2 \mathrm{~mm}$ sieve before analyzing it for $\mathrm{pH}$, EC, Organic carbon, Iron, Copper and Lead were calculated. After the normalization of data classical statistics was used to describe the soil properties and geo-statistical analysis was used to illustrate the spatial variability of the soil properties by using kriging interpolation techniques in a GIS environment. Results showed that the coefficient of variance for all the variables was 2.33 to 2.42 at depth $0-20 \mathrm{~cm}$ and 2.34 to 2.41 at depth $20-40 \mathrm{~cm}$. The geostatistical analysis was done by Ordinary kriging.
\end{abstract}

\section{Introduction}

Soil is a dynamic natural body which develops as a result of pedogenic natural processes during and after weathering of rocks. It consists of mineral and organic constituents, processing definite chemical, physical, mineralogical and biological properties having a variable depth over the surface of the earth and providing a medium for plant growth (Biswas and Mukherjee,
1994). Soil is a heterogeneous, diverse and dynamic system and its properties change in time and space continuously (Rogerio et al., 2006). Heterogeneity may occur at a large scale (region) or at small scale (community), even in the same type of soil or in the same community (Du Feng et al., 2008). Soil which is a natural resource has variability inherent to how the soil formation factors interact within the landscape. However, variability can occur also as a result of cultivation, land use and 
erosion. Salviano (1996) reported spatial variability in soil attributes as a result of land degradation due to erosion. Spatial variability of soil properties has been long known to exist and has to be taken into account every time field sampling is performed and investigation of its temporal and spatial changes is essential.

Geographical information system (GIS) technologies has great potentials in the field of soil and has opened newer possibilities of improving soil statistic system as it offers accelerated, repetitive, spatial and temporal synoptic view. It also provides a cost effective and accurate alternative to understanding landscape dynamics. GIS is a potential tool for handling voluminous data and has the capability to support spatial statistical analysis, thus there is a great scope to improve the accuracy of soil survey through the application of GIS technologies. Therefore, assessing spatial variability distribution on nutrients in relation to site characteristics including climate, land use, landscape position and other variables is critical for predicting rates of ecosystem processes (Schimel et al., 1991), understanding how ecosystem work (Townsend et al., 1995) and assessing the effects of future land use change on nutrients (Kosmas et al., 2000).

Out of the 118 elements in nature about 80 are metals, most of which are found only in trace amounts in the biosphere and in biological materials. There are at least some twenty metals like elements which give rise to well organize toxic effects in man and his ecological associates. Metals having density of more than $6 \mathrm{mg} / \mathrm{m}^{3}$ and atomic weight more than iron are called has heavy metals. Some metals and material and metalloids such as Zinc $(\mathrm{Zn})$, copper $(\mathrm{Cu})$, manganese $(\mathrm{Mn})$, Nickel (Ni), cobalt (Co), chromium (Cr) molybdenum $(\mathrm{Mb})$, and iron $(\mathrm{Fe})$ are the essential are essential for living organisms.

The contamination from automobiles are accumulated on the soil surface, move down to deep layers of soil and eventually change the soil physio-chemical properties directly or indirectly metals contamination in soil ranges from less than $1 \mathrm{ppm}$ to as high as 100,000 ppm due to human activity. The roadside environment represents a complex system for heavy metals in term of accumulation transport pathways and removal processes (Ghosh et al., 2003). Therefore, learning of the extent of heavy metals contamination on highway sites and its inflow into plant is highly relevant to the management of sustainable urban environmental quality everywhere. Study of the heavy metals contamination on highway sights soil and its accumulation highway side plant is highly relevant in India because of high urban development associated with an exponential rise in the number of vehicles on the highways having no effective pollution control standards.

Out of 4 study areas 2 are situated near the National mineral development corporation and 2 villages at different direction from it. The influence of the development of NMDC on the soil physicochemical characteristics is the primary objective of the study. Soil is a dynamic natural body which develops as a result of pedogenic natural processes during and after weathering of rocks. It consists of mineral and organic constituents, processing definite chemical, physical, mineralogical and biological properties having a variable depth over the surface of the earth and providing a medium for plant growth (Biswas and Mukherjee, 1994). Soil is a heterogeneous, diverse and dynamic system and its properties change in time and space continuously (Rogerio et al., 2006). Heterogeneity may occur at a large scale (region) or at small scale (community), even in the same type of soil or 
in the same community ( $\mathrm{Du}$ Feng et al., 2008). Soil which is a natural resource has variability inherent to how the soil formation factors interact within the landscape. However, variability can occur also as a result of cultivation, land use and erosion. Salviano (1996) reported spatial variability in soil attributes as a result of land degradation due to erosion. Spatial variability of soil properties has been long known to exist and has to be taken into account every time field sampling is performed and investigation of its temporal and spatial changes is essential.

Geographical information system (GIS) technologies has great potentials in the field of soil and has opened newer possibilities of improving soil statistic system as it offers accelerated, repetitive, spatial and temporal synoptic view. It also provides a cost effective and accurate alternative to understanding landscape dynamics. GIS is a potential tool for handling voluminous data and has the capability to support spatial statistical analysis, thus there is a great scope to improve the accuracy of soil survey through the application of GIS technologies. Therefore, assessing spatial variability distribution on nutrients in relation to site characteristics including climate, land use, landscape position and other variables is critical for predicting rates of ecosystem processes (Schimel et al., 1991), understanding how ecosystem work (Townsend et al., 1995) and assessing the effects of future land use change on nutrients (Kosmas et al., 2000). Out of the 118 elements in nature about 80 are metals, most of which are found only in trace amounts in the biosphere and in biological materials. There are at least some twenty metals like elements which give rise to well organize toxic effects in man and his ecological associates. Metals having density of more than $6 \mathrm{mg} / \mathrm{m}^{3}$ and atomic weight more than iron are called has heavy metals. Some metals and material and metalloids such as Zinc
$(\mathrm{Zn})$, copper $(\mathrm{Cu})$,manganese $(\mathrm{Mn})$, Nickel (Ni), cobalt (Co), chromium (Cr) molybdenum $(\mathrm{Mb})$, and iron $(\mathrm{Fe})$ are the essential are essential for living organisms.

The contamination from automobiles are accumulated on the soil surface, move down to deep layers of soil and eventually change the soil physio-chemical properties directly or indirectly metals contamination in soil ranges from less than $1 \mathrm{ppm}$ to as high as 100,000 ppm due to human activity. The roadside environment represents a complex system for heavy metals in term of accumulation transport pathways and removal processes (Ghosh et al., 2003). Therefore, learning of the extent of heavy metals contamination on highway sites and its inflow into plant is highly relevant to the management of sustainable urban environmental quality everywhere. Study of the heavy metals contamination on highway sights soil and its accumulation highway side plant is highly relevant in India because of high urban development associated with an exponential rise in the number of vehicles on the highways having no effective pollution control standards. Out of 4 study areas 2 are situated near the National mineral development corporation and 2 villages at different direction from it. The influence of the development of NMDC on the soil physicochemical characteristics is the primary objective of the study.

\section{Materials and Methods}

\section{Study area}

The study was carried out in Bastar district, Chattisgarh state, India (Fig. 1). It has its headquarters in the town of Jagdalpur. Jagdalpur has a monsoon type of hot tropical climate. Summers last from March to May and are hot, with the average maximum for May reaching $38.1^{\circ} \mathrm{C} \quad\left(100.6^{\circ} \mathrm{F}\right)$. The weather cools off somewhat for the monsoon 
season from June to September, which features very heavy rainfall. Winters are warm and dry. Its average rainfall is 1324.3 $\mathrm{mm}$. Its average temperature in summer is $33.15^{\circ} \mathrm{C}$, and in winter is $20.73^{\circ} \mathrm{C}$. Samples were collected from the 4 sampling sites, Kesloor and Raikot (NH-16), Adawal and Nagarnar (NH-43) in Jagdalpur. From each sites, 6 samples of soils (with three replications) from $20 \mathrm{~m}, 60 \mathrm{~m}$ and $500 \mathrm{~m}$ (control site) distance from the edge of national highway at two soil depths, $0-20 \mathrm{~cm}$, and 20-40 cm were collected. The soil samples were transferred in to air tight polythene bags and will be brought to the PG laboratory of Deptt. Of Soil Science and Agricultural Chemistry, SHUATS, Allahabad.

\section{Soil analysis}

The soil samples were air-dried, crushed and passed through a $2 \mathrm{~mm}$ sieve. Soil samples were analyzed for soil $\mathrm{pH}$ in both water and $0.01 \mathrm{M}$ potassium chloride solution (1:1) using glass electrode $\mathrm{pH}$ meter (McLean, 1982). EC was determined by using Digital Electrical conductivity method. Soil organic carbon was estimated by Walkley and Black method. Soil Iron, Copper and Lead was analysed by Wet digestion method, taking Aqua regia $\left(1: 3 \mathrm{HNO}_{3}: \mathrm{HCl}\right)$ for digestion and finding the results through AAS (Perkin Elmer A Analyst).

\section{Statistical analysis}

Statistical analysis for the work was done in two stages. Firstly, the distribution of data was described using conventional statistics such as mean, median, minimum, maximum, standard deviation (SD), skewness and kurtosis in order to recognize how data is distributed and each soil characteristics were investigated using descriptive statistics. Secondly, geo-statistical analysis was performed using the kriging interpolation technique within the spatial analyst extension module in ArcGis 10.2 software package to determine the spatial dependency and spatial variability of soil properties. Kriging method is a statistical estimator that gives statistical weight to each observation so their linear structure's has been unbiased and has minimum estimation variance (Kumke et al., 2005). This estimator has high application due to minimizing of error variance with unbiased estimation (Pohlmann, 1993). The experimental variogram model was constructed using the Kriging method, with data obtained from the research area. The spatial transformation was performed to determine the most appropriate model to use with the parameters of the generated maps.

The ordinary Kriging formula is as follows: (Isaaks and Srivastava, 1989; ESRİ, 2003).

$$
Z\left(S_{0}\right)=\sum i=1 N \lambda_{i} Z\left(S_{i}\right)
$$

where $Z(S i)$ is the measured value at the location ( $i$ th), $\lambda i$ is the unknown weight for the measured value at the location (ith) and $S 0$ is the estimation location. The unknown weight $(\lambda p)$ depends on the distance to the location of the prediction and the spatial relationships among the measured values.

The statistical model estimates the unmeasured values using known values. A small difference occurs between the true value $Z(S 0)$ and the predicted value, $\Sigma_{-} i Z(S i)$. Therefore, the statistical prediction is minimized using the following formula:

$$
\left[Z\left(S_{0}\right)-\sum i=1 N \lambda_{l} Z\left(S_{l}\right)\right]^{2}
$$

The Kriging interpolation technique is made possible by transferring data into the GIS environment. In this way, analysis in areas that have no data can be conducted. The following criteria were used to evaluate the model: the average error (ME) must be close 
to 0 and the square root of the estimated error of the mean standardized (RMSS) must be close to 1 (Johnston et al., 2001). While implementing the models, the anisotropy effect was surveyed.

\section{Results and Discussion}

Soil mapping and survey is an important activity because it plays a key role in the assessment of soil properties and its use in agriculture, irrigation and other land uses. This study was carried out to assess the spatial variability of some physical and chemical soil properties so as to determine their current situations in the study area, therefore the results can be presented as follows:

\section{Descriptive statistics}

The summary of the descriptive statistics of soil parameters as shown in Table 1 suggest that they were all normally distributed. The coefficient of variance for all the variables was 2.33 to 2.42 at depth $0-20 \mathrm{~cm}$ and 2.34 to 2.41 at depth $20-40 \mathrm{~cm}$. All the variables show low variation according to Coefficient of variance according to the guidelines provided by Warrick, 1998 for the variability of soil properties. The lowest coefficient of variation could be as a result of the uniform conditions in the area such as little changes in slope and its direction leading to a uniformity of soil in the area (Afshar et al., 2009; Cambardella et al., 1994; Kamare, 2010). Most of the soil properties were highly positively skew at both depths i.e. $\mathrm{pH}$ and EC at Raikot, Kesllor and Chokawada while $\% \mathrm{OC}, \mathrm{Fe}, \mathrm{Ni}$ and $\mathrm{Cr}$ were both symmetrical. These variations in chemical properties are mostly related to the different soil management practices carried out in the study area, the vehicle transportation, environmental pollution, parent material on which the soil is formed, role of the depth of ground water and irrigation water quality (Abel et al., 2014; Al-Atab, 2008; Al-Juboory et al., 1990).

\section{Geostatistical analysis}

The possible spatial structure of the different soil properties were identified by calculating the semivariograms and the best model that describes these spatial structures was identified. These results are shown in Tables 4 and 5 for the two depths. The model with the best fit was applied to each parameter, the Exponential and Gaussian model was the best fit for all parameters. The nugget effect (Co), the sill $(\mathrm{Co}+\mathrm{C})$ and the range of influence for each of the parameters were noted. The spatial dependencies (Nugget/Sill ratio) were found to be related to the degree of autocorrelation between the sampling points and expressed in percentages. Table 4 shows the soil properties where variable characteristics were generated from semivariogram model. $\mathrm{C} 0$ is the nugget variance; $\mathrm{C}$ is the structural variance, and $\mathrm{C} 0$ $+\mathrm{C}$ represents the degree of spatial variability, which affected by both structural and stochastic factors (Fig. 2 and 3). The higher ratio indicates that the spatial variability is primarily caused by stochastic factors, such as fertilization, farming measures, cropping systems and other human activities. The lower ratio suggests that structural factors, such as climate, parent material, topography, soil properties and other natural factors, play a significant role in spatial variability. The spatial dependent variables was classified as strongly spatially dependent if the ratio was $<25$, moderately spatially dependent if the ratio is between 25 and $75 \%$ while it is classified as weak spatial dependent if it $>75 \%$ (Cambardella et al., 1994; Clark, 1979; Erşahin, 1999; Robertson, 1987; Trangmar et al., 1985).

For the 0-20 cm depth, Ph, EC, \%OC, Fe, Ni and $\mathrm{Cr}$ had a strong spatial dependence with a 
ratio of $0.28, \quad 0, \quad 0.99, \quad 0, \quad 0$, and $0 \%$ respectively (Table 4).

At the lower depth i.e. $20-40 \mathrm{~cm} \mathrm{pH}, \mathrm{EC}$, $\% \mathrm{OC}, \mathrm{Fe}, \mathrm{Ni}$ and $\mathrm{Cr}$ had a strong spatial dependence $(0.214,0,0.99,0.475,0$ and $0.121 \%$ ) (Table 4 and Fig. 4-9).

The value of nugget effect for $\mathrm{EC}, \mathrm{Fe}$ and $\mathrm{Ni}$ were the lowest at both depths which suggest that the random variance of variables is low in the study area, this implies that near and away samples have similar and different values respectively. Therefore, nugget effects that is small and close to zero indicates a spatial continuity between the neighboring points, this can be backed with the results of Vieira and Paz Gonzalez (2003) and Mohammad Zamani et al., (2007).

The presence of a sill on the variogram indicates second-order stationarity, i.e. the variance and covariance exist (Table 2) (Geoff Bohling, 2005).

Table.1 Descriptive statistics within the field grid for the variables at depth $0-20 \mathrm{~cm}$

\begin{tabular}{|c|c|c|c|c|c|c|}
\hline \multicolumn{7}{|c|}{ Village Raikot (Distance fromNH at $20 \mathrm{~m}, 60 \mathrm{~m}$ and $500 \mathrm{~m}$ ) } \\
\hline Statistics & $\mathrm{pH}$ & $\mathrm{EC}$ & $\% \mathrm{OC}$ & $\mathrm{Fe}$ & $\mathrm{Ni}$ & $\mathrm{Cr}$ \\
\hline Mean & 6.30667 & .42367 & .89667 & 1585.00000 & 6.13333 & 6.33333 \\
\hline Median & 6.25000 & .40300 & .91000 & 2088.00000 & 7.50000 & 5.00000 \\
\hline SD & .162583 & .043822 & .080829 & 907.837541 & 3.647373 & 3.028751 \\
\hline Skewness & 1.378 & 1.650 & -.722 & -1.728 & -1.449 & 1.597 \\
\hline \multicolumn{7}{|c|}{ Village Kesloor (Distance fromNH at $20 \mathrm{~m}, 60 \mathrm{~m}$ and 500m) } \\
\hline Mean & 6.62333 & .48233 & .88333 & 2174.00000 & 12.93333 & 16.73333 \\
\hline Median & 6.60000 & .45700 & .88000 & 2176.00000 & 13.50000 & 15.30000 \\
\hline SD & .040415 & .145662 & .015275 & 37.040518 & 4.675824 & 2.569695 \\
\hline Skewness & 1.732 & .759 & .935 & -.242 & -.537 & 1.729 \\
\hline \multicolumn{7}{|c|}{ Village Adawal (Distance fromNH at $20 \mathrm{~m}, 60 \mathrm{~m}$ and 500m) } \\
\hline Mean & 7.06000 & .56033 & 1.07667 & 2287.33333 & 15.40000 & 25.33333 \\
\hline Median & 7.07000 & .55900 & 1.06000 & 2355.00000 & 13.50000 & 20.80000 \\
\hline SD & .017321 & .089007 & .037859 & 135.795189 & 4.838388 & 10.279267 \\
\hline Skewness & -1.732 & .067 & 1.597 & -1.686 & 1.495 & 1.599 \\
\hline \multicolumn{7}{|c|}{ Village Chokawada (Distance fromNH at $20 \mathrm{~m}, 60 \mathrm{~m}$ and $500 \mathrm{~m}$ ) } \\
\hline Mean & 6.87667 & .46133 & .92333 & 2279.66667 & 17.20000 & 41.43333 \\
\hline Median & 6.96000 & .46800 & .92000 & 2280.00000 & 16.90000 & 26.90000 \\
\hline SD & .153080 & .042395 & .025166 & .577350 & 2.662705 & 25.868385 \\
\hline Skewness & -1.724 & -.690 & .586 & -1.732 & .501 & 1.730 \\
\hline
\end{tabular}


Table.2 Descriptive statistics within the field grid for the variables at depth $20-40 \mathrm{~cm}$

\begin{tabular}{|c|c|c|c|c|c|c|}
\hline \multicolumn{7}{|c|}{ Village Raikot (Distance from NH at $20 \mathrm{~m}, 60 \mathrm{~m}$ and $500 \mathrm{~m}$ ) } \\
\hline Statistics & $\mathrm{pH}$ & $\mathrm{EC}$ & $\% \mathrm{OC}$ & $\mathrm{Fe}$ & $\mathrm{Ni}$ & $\mathrm{Cr}$ \\
\hline Mean & 6.23333 & .44033 & .74333 & 1057.00000 & 4.03333 & 1.16667 \\
\hline Median & 6.21000 & .42700 & .75000 & 1367.00000 & 2.90000 & .00000 \\
\hline SD & .116762 & .050342 & .050332 & 621.027375 & 3.635015 & 2.020726 \\
\hline Skewness & .863 & 1.108 & -.586 & -1.687 & 1.267 & 1.732 \\
\hline \multicolumn{7}{|c|}{ Village Kesloor (Distance from NH at 20 m, 60 m and 500m) } \\
\hline Mean & 6.61333 & .51867 & .74000 & 2081.33333 & 11.83333 & 11.76667 \\
\hline Median & 6.60000 & .46200 & .74000 & 2091.00000 & 11.10000 & 10.10000 \\
\hline SD & .023094 & .161630 & .020000 & 21.221059 & 4.247744 & 5.012318 \\
\hline Skewness & 1.732 & 1.384 & .000 & -1.625 & .754 & 1.331 \\
\hline \multicolumn{7}{|c|}{ Village Adawal (Distance from NH at 20 m, $60 \mathrm{~m}$ and 500m) } \\
\hline Mean & 7.00000 & .63933 & .90667 & 2060.33333 & 12.53333 & 16.26667 \\
\hline Median & 7.06000 & .64100 & .92000 & 2087.00000 & 10.70000 & 15.90000 \\
\hline SD & .112694 & .047522 & .032146 & 151.767366 & 3.980368 & 1.582193 \\
\hline Skewness & -1.717 & -.158 & -1.545 & -.766 & 1.633 & .987 \\
\hline \multicolumn{7}{|c|}{ Village Chokawada (Distance from NH at $20 \mathrm{~m}, 60 \mathrm{~m}$ and $500 \mathrm{~m}$ ) } \\
\hline Mean & 6.76667 & .48933 & .73333 & 2305.33333 & 30.46667 & 33.26667 \\
\hline Median & 6.71000 & .50200 & .72000 & 2354.00000 & 26.40000 & 35.40000 \\
\hline SD & .191398 & .055103 & .041633 & 84.293139 & 17.948909 & 7.433259 \\
\hline Skewness & 1.216 & -.980 & 1.293 & -1.732 & .967 & -1.185 \\
\hline
\end{tabular}

Table.3 Coefficient of variation within the field grid at depth $0-20 \mathrm{~cm}$ and $20-40 \mathrm{~cm}$

\begin{tabular}{|l|c|c|}
\hline Area & Cov (Depth 0-20 cm) & Cov (Depth 20-40cm) \\
\hline R $20 \mathrm{~m}$ & 2.41 & 2.41 \\
\hline R $60 \mathrm{~m}$ & 2.42 & 2.43 \\
\hline R $500 \mathrm{~m}$ & 2.37 & 2.38 \\
\hline K $20 \mathrm{~m}$ & 2.39 & 2.39 \\
\hline K $60 \mathrm{~m}$ & 2.4 & 2.41 \\
\hline K $500 \mathrm{~m}$ & 2.41 & 2.41 \\
\hline A $20 \mathrm{~m}$ & 2.36 & 2.39 \\
\hline A $40 \mathrm{~m}$ & 2.4 & 2.39 \\
\hline A $500 \mathrm{~m}$ & 2.4 & 2.4 \\
\hline C $20 \mathrm{~m}$ & 2.33 & 2.36 \\
\hline C $60 \mathrm{~m}$ & 2.38 & 2.39 \\
\hline C $500 \mathrm{~m}$ & 2.39 & 2.34 \\
\hline
\end{tabular}


Table.4 Geostatistical parameters of the fitted semivariogram models for soil properties and cross validation statistics at $0-20 \mathrm{~cm}$ depth and $20-40 \mathrm{~cm}$ depth respectively

\begin{tabular}{|c|c|c|c|c|c|c|c|c|}
\hline Variable & $\begin{array}{l}\text { Nugget } \\
\left(\mathrm{C}_{0}\right)\end{array}$ & $\begin{array}{l}\text { Sill } \\
\left(\mathbf{C}_{0}+\mathbf{C}\right)\end{array}$ & $\begin{array}{l}\text { Rang } \\
\text { e (A) }\end{array}$ & $\begin{array}{l}\text { Nugget/ } \\
\text { Sill }\end{array}$ & Model & $\begin{array}{l}\text { Spatial } \\
\text { Class }\end{array}$ & RMS & ME \\
\hline pH & 0.0069 & 0.241 & $\begin{array}{l}0.353 \\
4\end{array}$ & 0.28 & Exponential & strong & 0.152 & 0.038 \\
\hline EC & 0 & 0.0109 & $\begin{array}{l}0.138 \\
6\end{array}$ & 0 & Exponential & strong & 0.099 & 0.0389 \\
\hline OC & 3.81 & 3.825 & $\begin{array}{l}0.170 \\
1\end{array}$ & 0.99 & Exponential & strong & 0.058 & 0.255 \\
\hline $\mathrm{Fe}$ & 0 & $\begin{array}{l}230769 . \\
6\end{array}$ & 0.138 & 0 & Exponential & strong & 515.79 & 0.057 \\
\hline $\mathrm{Cu}$ & 0 & 22.40 & 0.138 & 0 & Exponential & strong & 4.046 & 0.049 \\
\hline $\mathbf{P b}$ & 181.26 & 0 & 0.353 & 0 & Exponential & Strong & 15.22 & 0.044 \\
\hline Variable & $\begin{array}{l}\text { Nugget }( \\
\left.\mathrm{C}_{0}\right)\end{array}$ & $\begin{array}{l}\text { Sill } \\
\left(\mathbf{C}_{0}+C\right)\end{array}$ & $\begin{array}{l}\text { Rang } \\
\text { e (A) }\end{array}$ & $\begin{array}{l}\text { Nugget/ } \\
\text { Sill }\end{array}$ & Model & $\begin{array}{l}\text { Spatial } \\
\text { Class }\end{array}$ & RMS & ME \\
\hline pH & 0.030 & 0.11 & 0.252 & 0.215 & Exponential & Strong & 0.207 & 0.016 \\
\hline EC & 0 & 0.016 & 0.132 & 0 & Exponential & Strong & 0.121 & 0.060 \\
\hline OC & 1.30 & 1.313 & 0.16 & 0.99 & Gaussian & Strong & 0.080 & 0.120 \\
\hline $\mathbf{F e}$ & $\begin{array}{l}211036 . \\
30\end{array}$ & $\begin{array}{l}444118 . \\
8\end{array}$ & 0.353 & 0.475 & Exponential & Strong & 535.15 & 0.027 \\
\hline $\mathbf{N i}$ & 0 & 194.33 & 0.132 & 0 & Exponential & strong & 12.69 & 0.057 \\
\hline $\mathrm{Cr}$ & 34.64 & 286.12 & 0.353 & 0.121 & Exponential & strong & 7.85 & 0.016 \\
\hline
\end{tabular}

Fig.1 Map of the study area of Bastar district, Chhattisgarh, India showing the sample locations
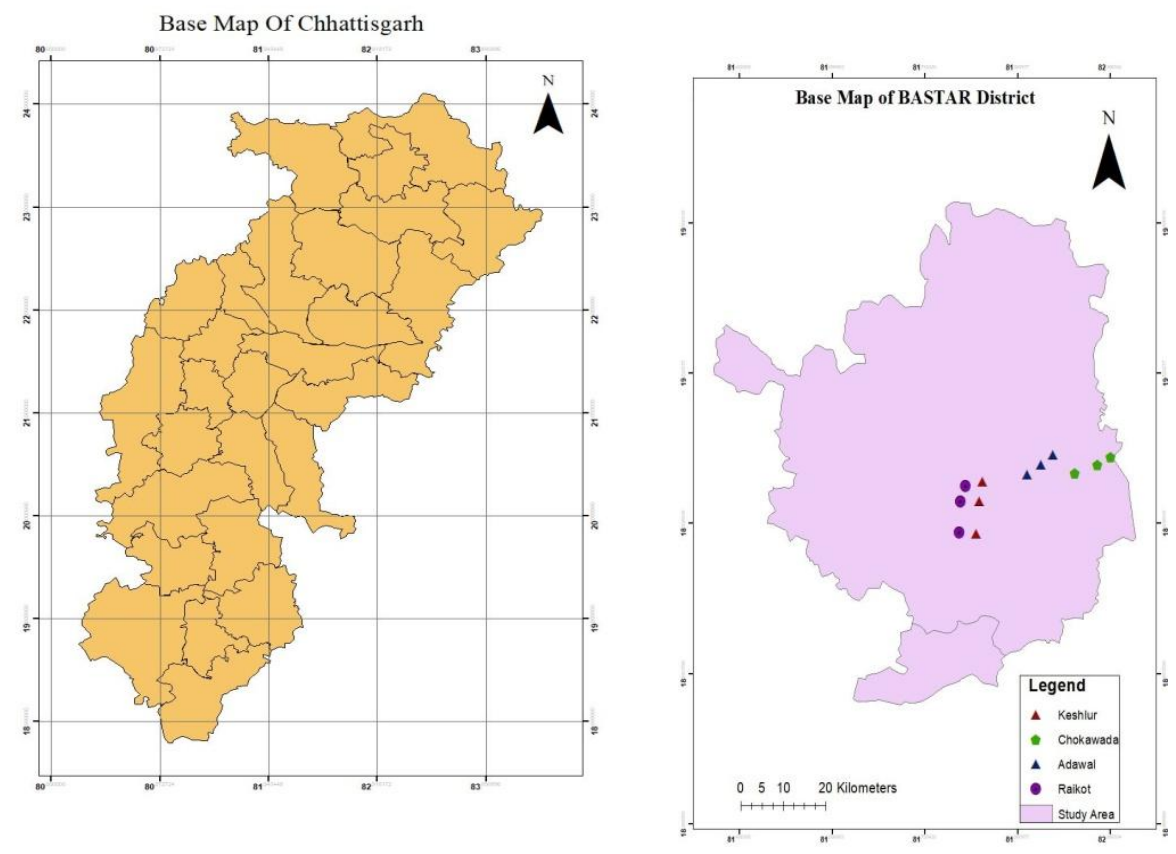
Fig.2 Semivariogram parameters of best fitted theoretical model to predict soil properties at 0-20 cm depth, a. pH b. EC c. \%OC d. Fe e. $\mathrm{Cu}$ and f. $\mathrm{Pb}$
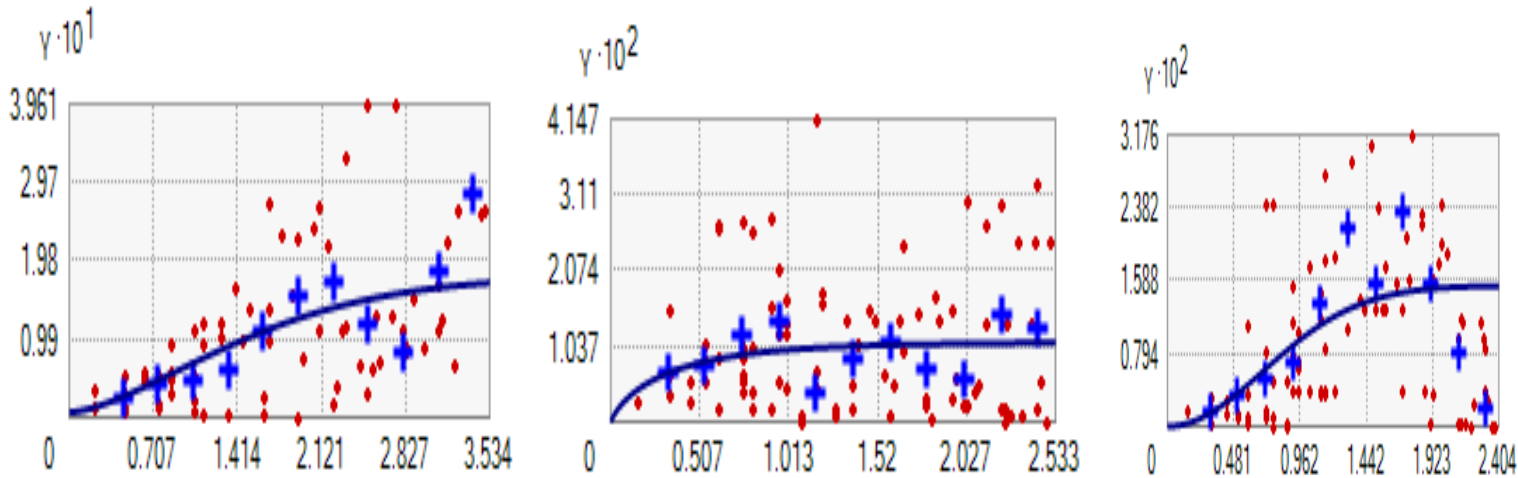

- Model. Binned \& Averaged Distance, $h \cdot 10^{1}=$ Model - Binned \& Averaged Distance, $h \cdot 10^{1}$

(a)

(b)

- Model 1 Binned \& Averaged Distance, $h \cdot 10^{1}$

(c)

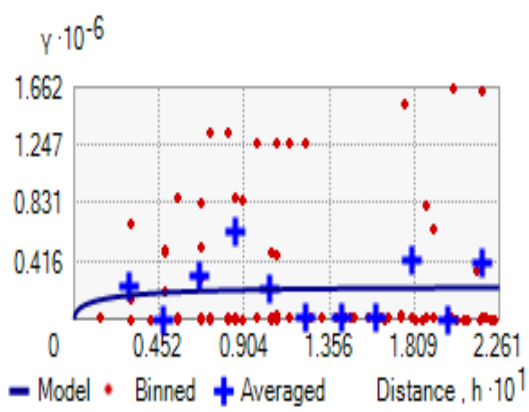

(d)

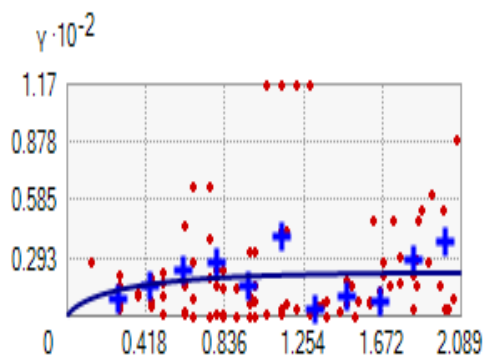

- Model $\cdot$ Binned + Averaged Distance, $h \cdot 10^{1}$

(e)

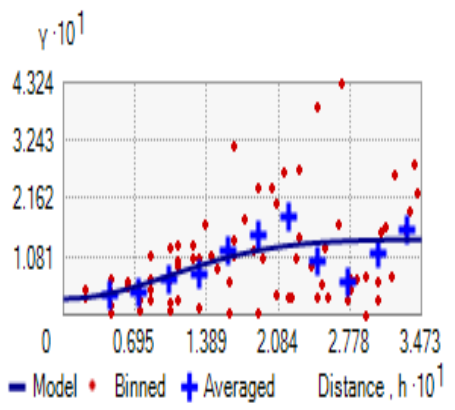

(f)

Fig.3 Semivariogram parameters of best fitted theoretical model to predict soil properties at 20$40 \mathrm{~cm}$ depth, a. pH b. EC c. \%OC d. Fe e. Ni and f. Cr

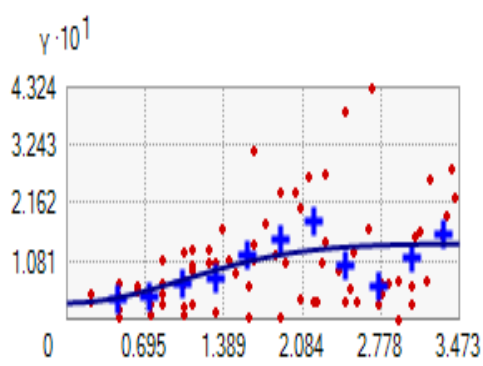

- Model $\cdot$ Binned + Averaged Distance, $h \cdot 10^{1}$

(a)

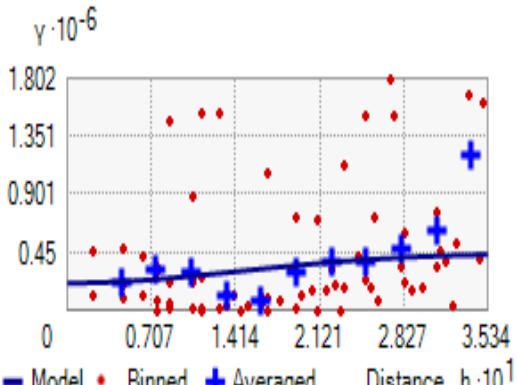

(d)

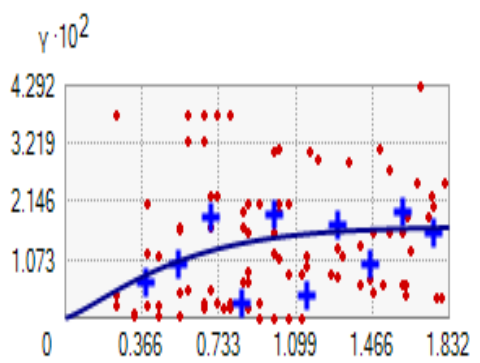

- Model $\cdot$ Binned + Averaged Distance, $h \cdot 10^{1}$

(b)

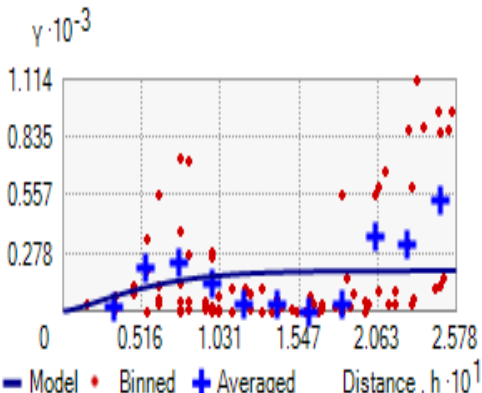

(e)

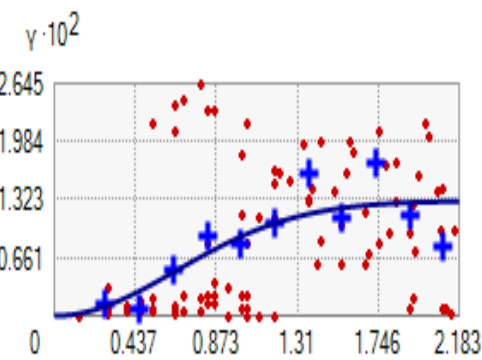

- Model $\cdot$ Binned + Averaged Distance, $h \cdot 10^{1}$

(c)

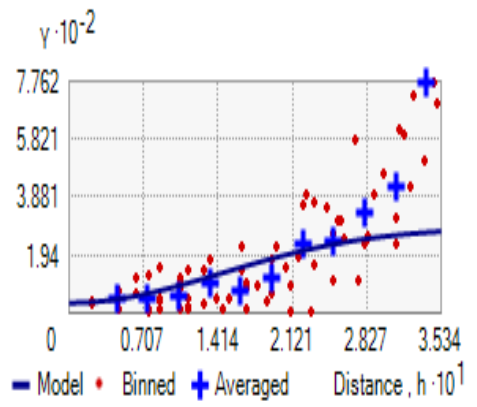

(f) 
Fig.4 (a) $\mathrm{pH}$ at $0-20 \mathrm{~cm}$ and (b) $\mathrm{pH}$ at $20-40 \mathrm{~cm}$

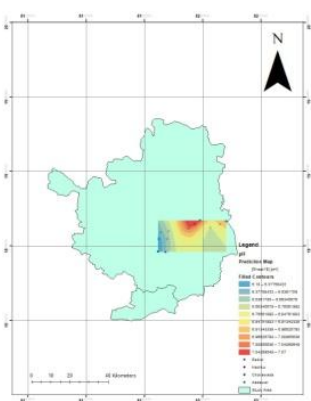

(a)

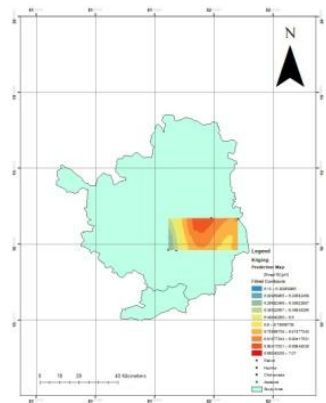

(b)

Fig.5 (a) EC at $0-20 \mathrm{~cm}$ and (b) EC at $20-40 \mathrm{~cm}$

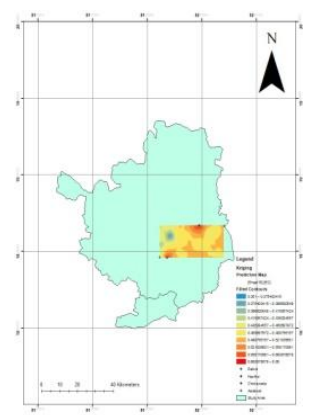

(a)

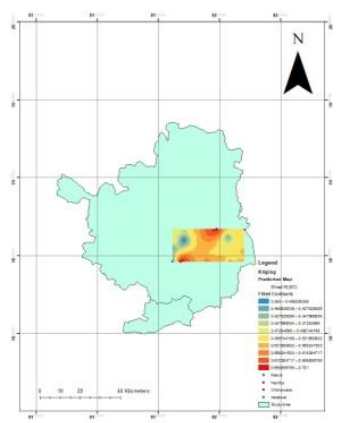

(b)

Fig.6 (a) OC at $0-20 \mathrm{~cm}$ and (b) OC at $20-40 \mathrm{~cm}$

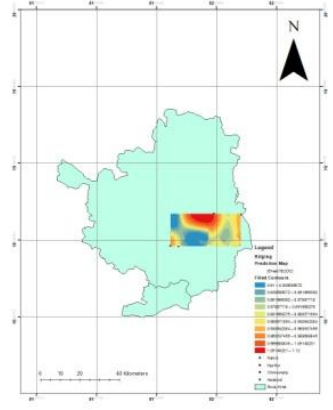

(a)

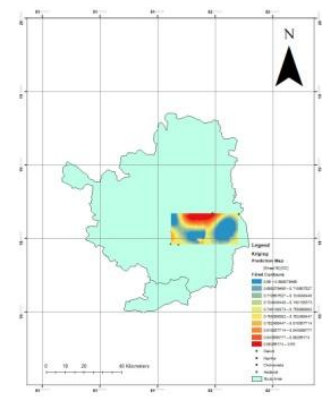

(b)

Fig.7 (a) Fe at $0-20 \mathrm{~cm}$ and (b) $\mathrm{Fe}$ at $20-40 \mathrm{~cm}$

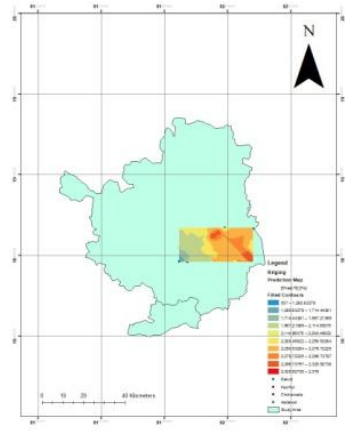

(a)

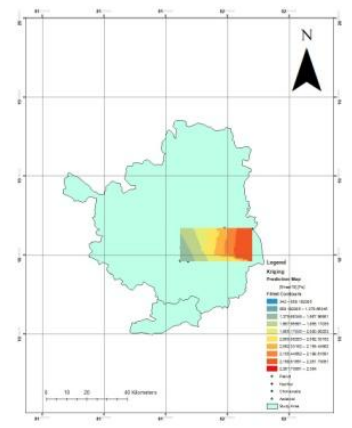

(b) 
Fig.8 (a) Ni at $0-20 \mathrm{~cm}$ and (b) Ni at $20-40 \mathrm{~cm}$

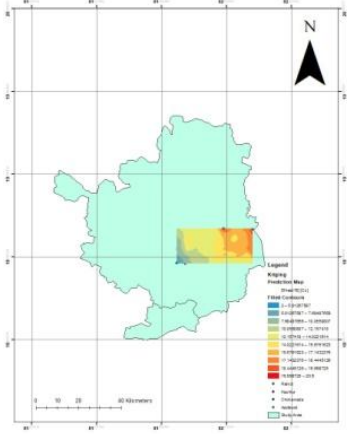

(a)

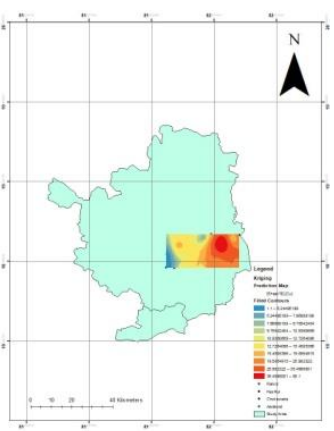

(b)

Fig.9 (a) $\mathrm{Cr}$ at $0-20 \mathrm{~cm}$ and (b) $\mathrm{Cr}$ at $20-40 \mathrm{~cm}$

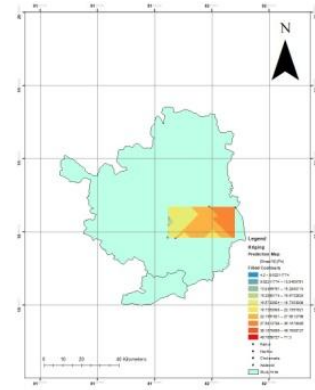

(a)

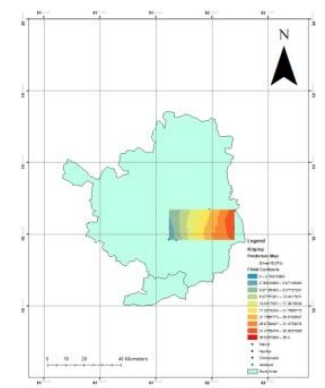

(b)
In conclusion, assessing spatial variability and mapping of soil properties is an important pre-requisite for soil and crop management and also useful in identifying land degradation spots. The production of soil nutrient maps is the first step in precision agriculture because these maps will measure spatial variability and provide the basis for controlling it. It would also help in reducing the amount of inputs been added to the soil in form of supplements so as not to over burden the soil which can lead to pollution thereby degrading the land. The results shows that the spatial distribution and spatial dependence level of soil properties can be different even within the same local government area. It also demonstrates the effectiveness of GIS techniques in the interpretation of data. These results can be used to make recommendations of best management practices within the locality and also to improve the livelihood of smallholder farmers.

\section{References}

Abel, C., Kutywayo, D., Chagwesha, T. M., and Chidoko, P. (2014). Assessment of irrigation water quality and selected soil parameters at Mutema irrigation scheme, Zimbabwe. Journal of Water Resources and Protection, 6, 132-140.

Afshar, H., Salehi, M. H., Mohammadi, J., and Mehnatkesh, A. (2009). Spatial variability of soil properties and irrigated wheat yield in quantitative suitability map, a case study: Share e Kian Area, Chaharmahaleva Bakhtiari province. Journal of Water and Soil, 23, 161-172.

Al-Atab, S. M. S. (2008). Variations of soil properties and classification in some area of Basrah Governorate (PhD Thesis). College of Agriculture, University of Basrah, Basrah.

Al-Juboory, S. R., Alaqid, W. K. Alaqidi and 
Al-Issawi, S. M. (1990). Effect of soil management practices on Chemical and physical properties of a soil from great Mussayb Project. Iraqi journal of Agriculture Sciences, 21, 107-116.

Biswas, T. D., and Mukherjee, S. K. (1994). Textbook of soil science. New Delhi: Tata McGraw-Hill Publishing Company Limited.

Black, C. A. (1965). Methods of soil analysis. Agronomy No. 9, Part 2. Madison, WI: American Society of Agronomy.

Brown, G., Newman, A. C. D., Rayner, J. H., Weir, A. H. (1978). The structure and chemistry of soil clay minerals In D. J. Greenland and M. H. B. Hayes (Eds.), The chemistry of soil constituents(pp. 29178). New York, NY: Wiley.

Buol, S. W., Hole, F. D., McCracken, R. J., and Southard, R. J. (1997). Soil genesis and classification (4th ed., p. 527). Ames: Iowa State University Press.

Cambardella, C. A., and Karlen, D. L. (1999). Spatial analysis of soil fertility parameters. Precision Agriculture, 1, 514.

Cambardella, C. A., Moorman, T. B., Parkin, T. B., Karlen, D. L., Novak, J. M., Turco, R. F., and Konopka, A. E. (1994). Field-scale variability of soil properties in central Iowa soils. Soil Science Society of America Journal, 58, 1501-1511. http:// dx.doi.org/10.2136/sssaj1994.03615995 $005800050033 \mathrm{x}$

Clark, I. (1979). Practical geostatistics (p. 129). London: Applied Science Publishers.

Du Feng, L. Z., XuXuexuan, Z. X., and Shan, L. (2008). Spatial heterogeneity of soil nutrients and aboveground biomass in abandoned old-fields of Loess Hilly region in Northern Shaanxi, China. Acta Ecologica Sinica, 28, 13-22.

Erşahin, S. (1999). Alluvial soil in a field, some physical and chemical properties of the spatial variability of the determination. $S U$ Journal of the Faculty of Agriculture, 13, 34-41.

ESRİ. (2003). The principles of geostatistical analysis (p. 54). Federal Fertilizer Department. Federal Ministry of Agriculture and Rural development. (2012). Fertilizer use and management practices for crops in Nigeria (4th ed., pp. 40-41).

Isaaks, E. H., and Srivastava, R. M. (1989). An introduction to applied geostatistics. New York, NY: Oxford University Press.

Jackson M. L. (1958). Soil chemical analysis (p. 125). Engle wood cliffs, NJ: Prentice Hall.

Johnston, K., Hoef, M., Krivoruchko, K., and Lucas, N. (2001). Using ArcGIS geostatistical analyst. New York, NY: ESRI.

Kamare, R. (2010). Spatial variability of production, density and canopy cover percentage of Nitrariaschoberi L. in Meyghan Playa of Arak by using geostatistical methods (M.Sc Thesis,

76pp). Tarbiat Modares University, Tehran.

Kosmas, C., Gerontidis, St., and Marathianou, M. (2000). The effect of land use change on soils and vegetation over various lithological formations on Lesvos (Greece). Cantena, 40, 51-68.

Kumke, T., Schoonderwaldt, A., and Kienel, U. (2005). Spatial variability of sedimentological properties in a large Siberian lake. Aquatic Sciences, 67, 8696. http://dx.doi.org/10.1007/s00027004-0734-5

López-Granados, F., Jurado-Expósito, M., Atenciano, S., García- Ferrer, A., Sánchez de la Orden, M. S., and GarcíaTorres, L. (2002). Spatial variability of agricultural soil parameters in southern Spain. Plant and Soil, 246, 97-105. http://dx.doi.org/10.1023/A:102156841 5380 
McLean, E. O. (1982). Soil pH and lime requirement. In A. L. Page (Ed.), Methods of soil analysis part 2. Madison, WI: ASA-SSSA.

Mohammad Zamani, S., Auubi, S., and Khormali, F. (2007). Investigation of spatial variability soil properties and wheat production in some of farmland of sorkhkalateh of Golestan province. Journal of Science and Technical Agriculture and Natural Recourses, 11, 79-91.

Pohlmann, H. (1993). Geostatistical modelling of environmental data. CATENA, 20, 191-198. http://dx.doi.org/10.1016/0341-
8162(93)90038-Q

Robertson, G. P. (1987). Geostatistics in ecology: Interpolating with known variance. Ecology, 68, 744-748. http://dx.doi.org/10.2307/1938482

Rogerio, C., Ana, L. B. H., and de Quirijn, J. L. (2006). Spatiotemporal variability of soil water tension in a tropical soil in Brazil. Geoderma, 133, 231-243.

Salviano, A. A. C. (1996). Variabilidade de atributos de solo e crotalária júncea em solo degradado do município de Piracicaba - SP (p. 91). Piracicaba: Tese (Doutorado), Escola Superior de Agricultura Luiz de Queiroz, Universidade de São Paulo.

\section{How to cite this article:}

Smriti Rao, P., Tarence Thomas, Amit Chattree, Joy Dawson and Narendra Swaroop. 2019. Spatial Analysis of Soil Chemical Properties of Bastar District, Chhattisgarh, India. Int.J.Curr.Microbiol.App.Sci. 8(04): 2185-2197. doi: https://doi.org/10.20546/ijcmas.2019.804.257 